\title{
Microstructure and Mechanical Properties of Ti-Al Explosive Composite Plate after Heat Treatment
}

\author{
Shaogang Wang ${ }^{\mathrm{a}}$, Hongbo Xia ${ }^{\mathrm{b}}$, Xiaomin Han and Yan Huang \\ College of Material Science and Technology, Nanjing University of Aeronautics and Astronautics, \\ Nanjing,Jiangsu, 210016, China \\ asgwang@nuaa.edu.cn, bjssrxhb@126.com
}

\begin{abstract}
Keywords: Explosive welding, Ti-Al composite plate, Microstructure, Mechanical properties, Heat treatment.

Abstract. Annealing treatment is carried out for the TA2-2A12 explosive composite plate under the heating temperature of $440^{\circ} \mathrm{C}$ and $480^{\circ} \mathrm{C}$ with duration time of $1 \mathrm{~h}, 3 \mathrm{~h}, 6 \mathrm{~h}$ and $9 \mathrm{~h}$ respectively. The microstructure and mechanical properties of composite plate are investigated after annealing. Results show that recovery and recrystallization occurred near interface of composite plate after heat treatment. And the longer duration time is, the bigger the size of grains is. The shear strength of composite plate reaches the maximum value of $82.3 \mathrm{MPa}$ under the condition of $440^{\circ} \mathrm{C} \times 3 \mathrm{~h}$. The microhardness measurement demonstrates that the mcirohardness decreases in direct proportion to the heating temperature and duration time. EDS analyses indicate that three kinds of intermetallic compounds $\left(\mathrm{TiAl}_{3}, \mathrm{TiAl}_{1} \mathrm{TiAl}_{2}\right)$ formed near interface of composite plate undergone the annealing process of $480^{\circ} \mathrm{C} \times 9 \mathrm{~h}, 440^{\circ} \mathrm{C} \times 6 \mathrm{~h}, 480^{\circ} \mathrm{C} \times 6 \mathrm{~h}$, respectively. The shear strength of composite plate decreases resulting from the formation of intermetallic compounds. Considering all of the influencing factors, $440^{\circ} \mathrm{C} \times 3 \mathrm{~h}$ is determined as the optimized annealing process in present work.
\end{abstract}

\section{Introduction}

Titanium-aluminum composite plate has the properties of high temperature resistance and corrosion resistance from titanium and low density and good heat conductivity from aluminum, namely, it has excellent comprehensive properties. Ti-Al composite plate will be widely used in many fields such as aerospace and petrochemical industry, etc[1]. At present, the preparation of Ti-Al composite plate and the microstructure and mechanical properties of composite plate are investigated by many researchers, and great progress has been made. During the manufacturing process of Ti-Al composite plate, the combination between $\mathrm{Ti}$ and $\mathrm{Al}$ is through severe plastic deformation associated with explosion, and the quality of composite plate depends on many technological factors. The residual stress can be relieved and the microstructure and properties of composite plate can be greatly improved by post-weld heat treatment[2,3]. Based on these, in terms of the heat treatment technology of titanium and aluminum, the appropriate heat treatment process is selected for annealing of Ti-Al composite plate. The microstructure and mechanical properties of composite plate are investigated after heat treatment, and the heat treatment parameters are optimized under the experimental condition, so the guidance can be provided for the practical application of Ti-Al composite plate.

\section{Experimental materials and procedure}

The base metals are industrial pure titanium TA2(annealing state) with the dimension of $500 \mathrm{~mm} \times 200 \mathrm{~mm} \times 2 \mathrm{~mm}$ and aluminum alloy $2 \mathrm{~A} 12$ (quenching and natural aging state) with the dimension of $500 \mathrm{~mm} \times 200 \mathrm{~mm} \times 6 \mathrm{~mm}$, respectively. Their chemical compositions are $(\mathrm{wt} \%)$ : TA2(Ti, $\leq 0.30 \mathrm{Fe}, \leq 0.10 \mathrm{C}, \leq 0.05 \mathrm{~N}, \leq 0.25 \mathrm{O}, \leq 0.015 \mathrm{H}), 2 \mathrm{~A} 12(\mathrm{Al}, 3.8-4.9 \mathrm{Cu}, 1.2-1.8 \mathrm{Mg}, 0.3-0.9 \mathrm{Mn}, \leq 0.50 \mathrm{Fe}$, $\leq 0.50 \mathrm{Si}, \leq 0.30 \mathrm{Zn}, \leq 0.10 \mathrm{Ni}, \leq 0.15 \mathrm{Ti}, \leq 0.65$ the other elements). The mechanical properties of base metals are given in Table 1 . The TA2-2A12 composite plates are fabricated by explosive welding (EW). 
Table 1 The mechanical properties of base metals

\begin{tabular}{cccccc}
\hline Base metal & Treatment state & $\begin{array}{c}\text { Tensile strength } \\
\sigma_{\mathrm{b}} / \mathrm{MPa}\end{array}$ & $\begin{array}{c}\text { Yield strength } \\
\sigma_{\mathrm{s}} / \mathrm{MPa}\end{array}$ & $\begin{array}{c}\text { Elongation } \\
\delta / \%\end{array}$ & $\begin{array}{c}\text { Hardness } \\
\mathrm{HV} / \mathrm{MPa}\end{array}$ \\
\hline TA2 & $\begin{array}{c}\text { Annealing } \\
2 \mathrm{~A} 12\end{array}$ & $\geq 441$ & $\geq 373$ & 25 & $\geq 140$ \\
$\begin{array}{c}\text { Quenching + natural } \\
\text { aging }\end{array}$ & $\geq 410$ & $\geq 305$ & 17 & $\geq 50$ \\
\hline
\end{tabular}

After explosive welding, the interfacial microstructure of Ti-Al composite plate is observed by using MM6 optical microscope. The substructure of composite plate is analyzed by using FEI Tecnai G2 transmission electron microscope(TEM). The annealing of composite plate is conducted at heating temperature $440^{\circ} \mathrm{C}$ and $480^{\circ} \mathrm{C}$, and duration time $1 \mathrm{~h}, 3 \mathrm{~h}, 6 \mathrm{~h}$ and $9 \mathrm{~h}$, respectively. The effect of different heat treatment processes on microstructure and mechanical properties are investigated. The tests of mechanical properties include shear strength and microhardness. The line scanning analyses of elements $\mathrm{Ti}$ and $\mathrm{Al}$ are conducted near the interface of composite plate by using energy dispersive spectrometer(EDS). After heat treatment, the probable formation regions of intermetallic compound in interface will be calibrated, thus the types of intermetallic compounds are determined.

\section{Microstructure of bonding interface of composite plate in as-welded state}

In the course of EW, there are often three types of interfaces, i.e. straight, wavy and melted layer[3,4]. The wavy interface is usually expected to obtain during EW, because the interlocking area in wavy pattern is larger than that in straight pattern. Consequently, the practical bonding area of composite plate at interface can be further increased. The microstructure of composite plate at interface is shown in Fig.1. From Fig.1, the interface of composite plate presents the wavy connection which is expected.

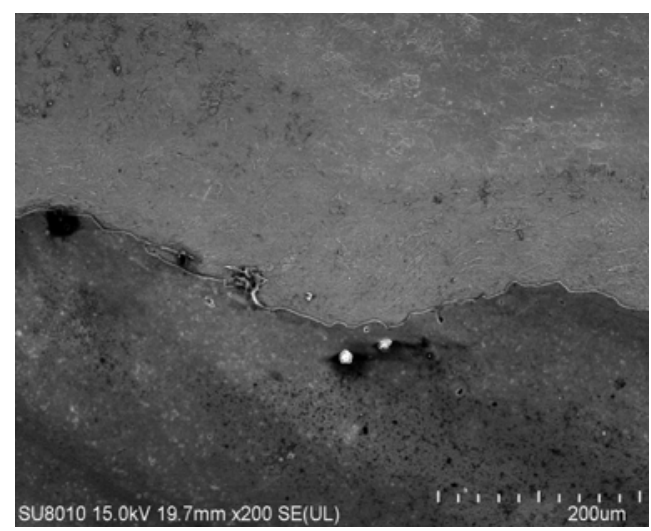

Fig.1 Microstructure with wavy interface after explosive welding

At the sides of titanium and aluminum, interfacial microstructure is shown in Fig.2. From Fig.2(a) and (b), it can be seen that the grain size of aluminum crystal is not identical, and the size of small grain is about $500 \mathrm{~nm}$, while the size of big grain is about $2 \mu \mathrm{m}$. All of the aluminum grains stretch along a certain direction, which is consistent with explosive direction. The shape of grain is typical polygon, due to the release of heat during explosive welding process, which results from the acceleration of polygonization process of plastic deformation metal. From Fig.2(c) and (d), the dislocation density within grain at the side of titanium is higher than that at the side of aluminum, because the softening temperature of titanium is higher than that of aluminum. Dislocations mainly concentrate on the grain boundary, because the severe plastic deformation will occur under the action of explosive pressure, which causes the movement of dislocation line in crystal, and dislocations tangle each other. It causes dislocations distributed inhomogeneously within grains, and the cellular substructure of dislocation formed. Cellular substructure with high density readily migrates to grain boundary to form cell wall, as a result, the dislocation density decreases within cell. 

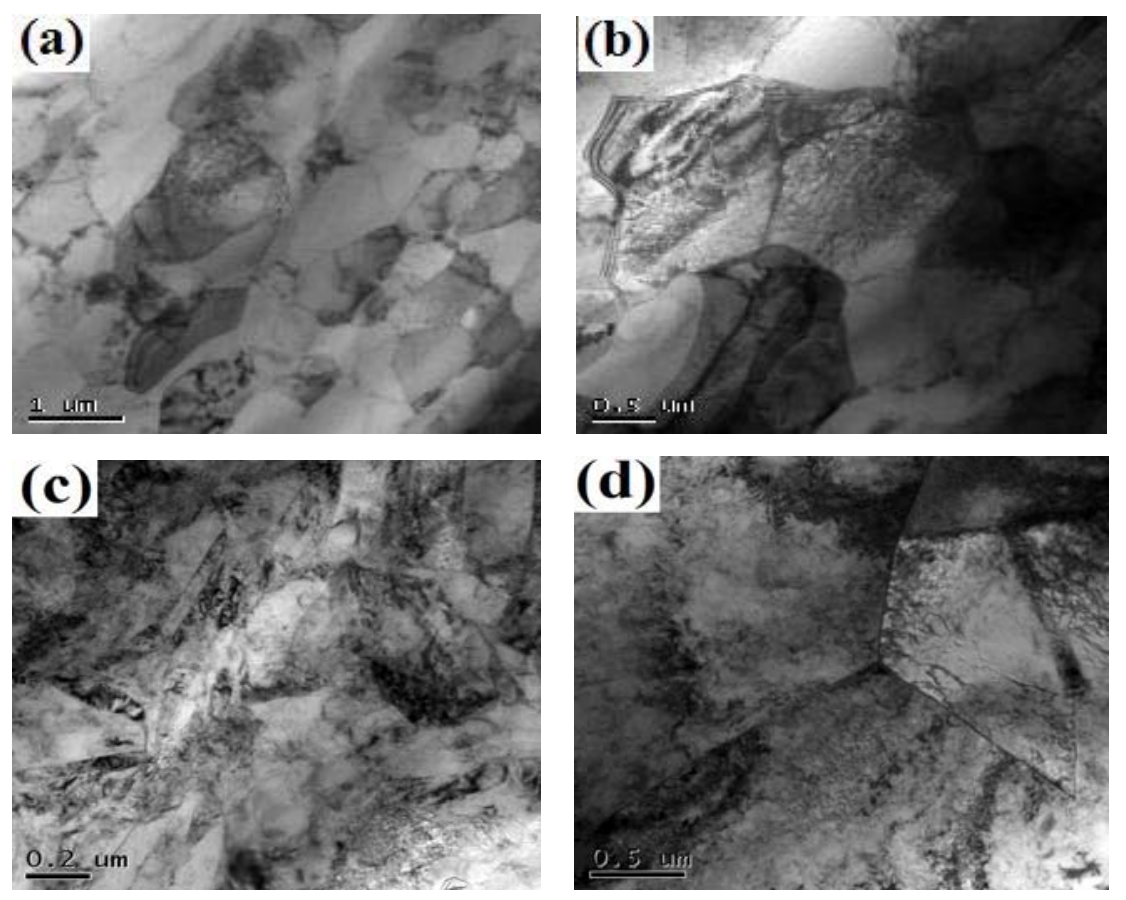

Fig.2 Microstructure of titanium and aluminum sides near interface:

(a)microstructure at the side of aluminum, (b)dislocations within Al grain boundary, (c)microstructure at the side of titanium, and (d)dislocations within Ti grain boundary

\section{Microstructure of bonding interface of composite plate after heat treatment}

Microstructure at the side of titanium near interface after heat treatment is shown in Fig.3. Compared to Fig.1, there are still fine grains in interface after annealing. However, when it is a little distant from interface, grains grow to a certain extent, and the size and shape of grains are different, the big grain and the small grain distribute mixedly, the fiber structure stretched along explosive direction and broken original structure in as-welded state is eliminated. It demonstrates that the processes of recovery, recrystallization and grain growth occurred to this region, as shown in Fig.3(a). The grain at the side of titanium is obviously big, and it distributes uniformly, because the processes of recovery and recrystallization of grains proceed more fully with the increase of heat input, as shown in Fig.3(b).
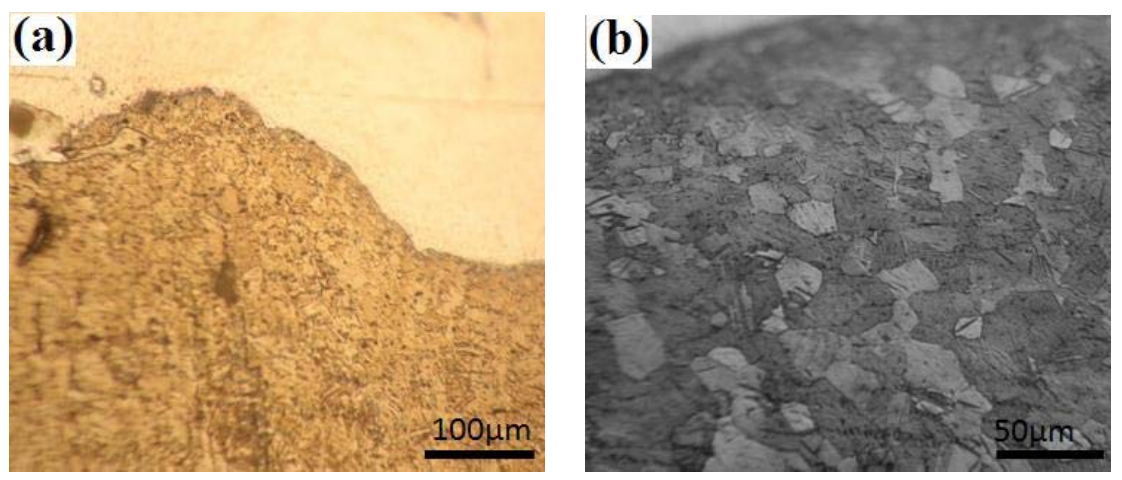

Fig.3 Microstructure of the side of titanium near interface after heat treatment:

(a) $440^{\circ} \mathrm{C} \times 3 \mathrm{~h}$, and (b) $480^{\circ} \mathrm{C} \times 9 \mathrm{~h}$

\section{Distribution of alloy elements at interface after heat treatment}

The position of line scanning of alloy element and the EDS curves of elements Ti and Al under different heat treatment conditions are shown in Fig.4 respectively. From the curves in Fig.4, it can be seen that the diffusion area of elements $\mathrm{Ti}$ and $\mathrm{Al}$ in matrix gradually becomes large with the increase 
of duration time. According to the Ti-Al diagram, the solubility is little between $\mathrm{Ti}$ and $\mathrm{Al}$, when the element concentration is in excess of the solubility between $\mathrm{Ti}$ and $\mathrm{Al}$, the intermetallic compound will easily generate. The hardness and brittleness of intermetallic compound between $\mathrm{Ti}$ and $\mathrm{Al}$ are high, and it has great disadvantages to the bonding strength of interface of composite plate. Thus, the formation of intermetallic compound should be avoided or reduced as much as possible when the heat treatment process is conducted, so the enough strength of interface can be possessed for the composite plate.

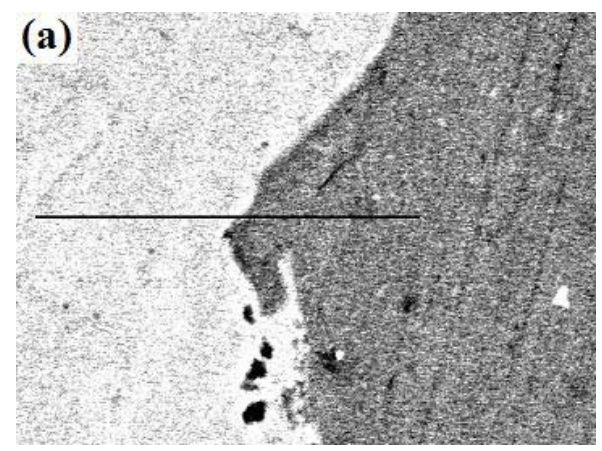

(b)

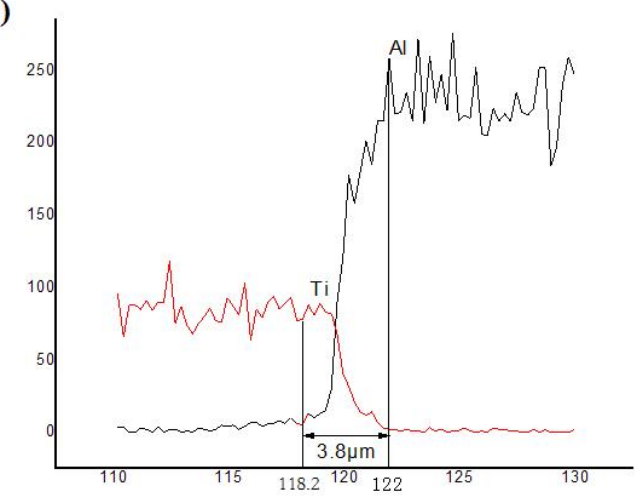

(d)

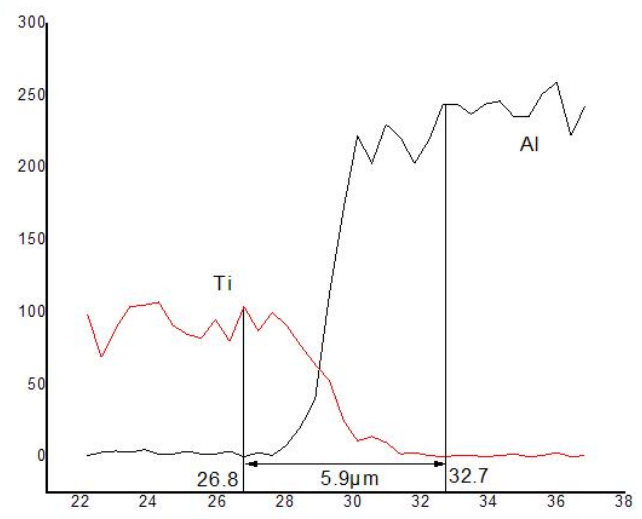

(c)

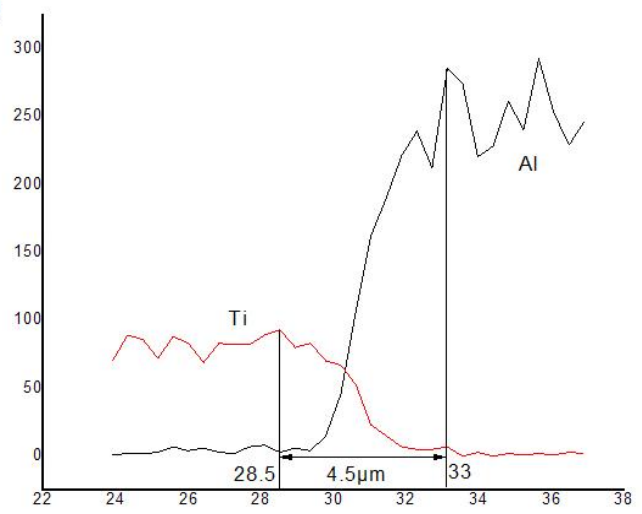

(e)

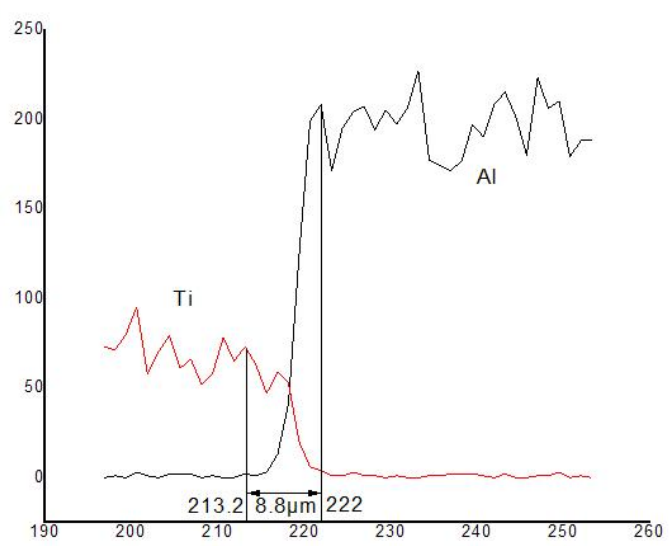

Fig.4 The position of line scanning and EDS curves under different heat treatment conditions: (a)position of line scanning, (b)element distribution in $480^{\circ} \mathrm{C} \times 1 \mathrm{~h}$, (c)element distribution in $480^{\circ} \mathrm{C} \times 3 \mathrm{~h}$, (d)element distribution in $480^{\circ} \mathrm{C} \times 6 \mathrm{~h}$, and (e)element distribution in $480^{\circ} \mathrm{C} \times 9 \mathrm{~h}$

\section{The formation of intermetallic compound at interface after heat treatment}

According to the literature[5], the compound phase possibly produced in Ti-Al system can be predicted. The formation area and its corresponding curves of EDS are respectively shown in Fig.5 for intermetallic compound at interface of composite plate after heat treatment. And the atom ratio and the pattern of intermetallic compound to corresponding area are given in Table 2. From Fig.5, it can be seen that $\mathrm{TiAl}_{3}$ and $\mathrm{TiAl}$ present the pattern of isolated island, while the $\mathrm{TiAl}_{2}$ presents the 
discontinuous distribution of band. The generation of these intermetallic compounds is probably that a little elements $\mathrm{Ti}$ and $\mathrm{Al}$ mixed together after $\mathrm{EW}$ to form mechanical mixture of elements. Diffusion between the two elements accelerates during annealing, which results in more $\mathrm{Ti}$ and $\mathrm{Al}$ atoms to mix each other. Due to the limited solubility between $\mathrm{Ti}$ and $\mathrm{Al}$, when the element concentration is in excess of the limit of solubility, the intermetallic compound maybe produces in the course of holding temperature. Because the intermetallic compound is disadvantageous to the interface of composite plate, the formation of such intermetallic compound should be avoided during the manufacturing of composite plate.

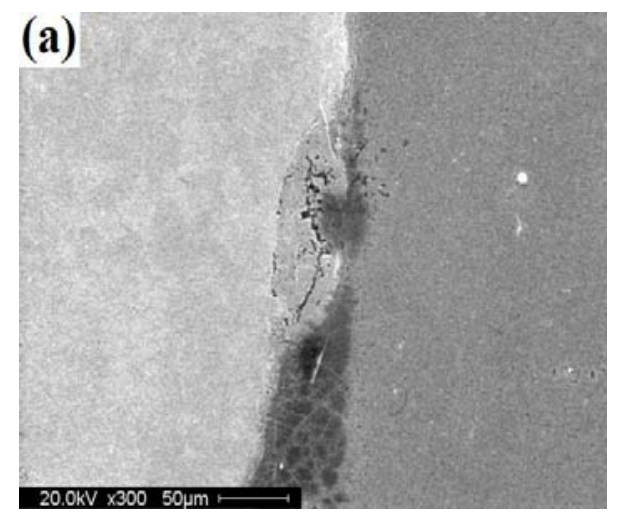

(d)
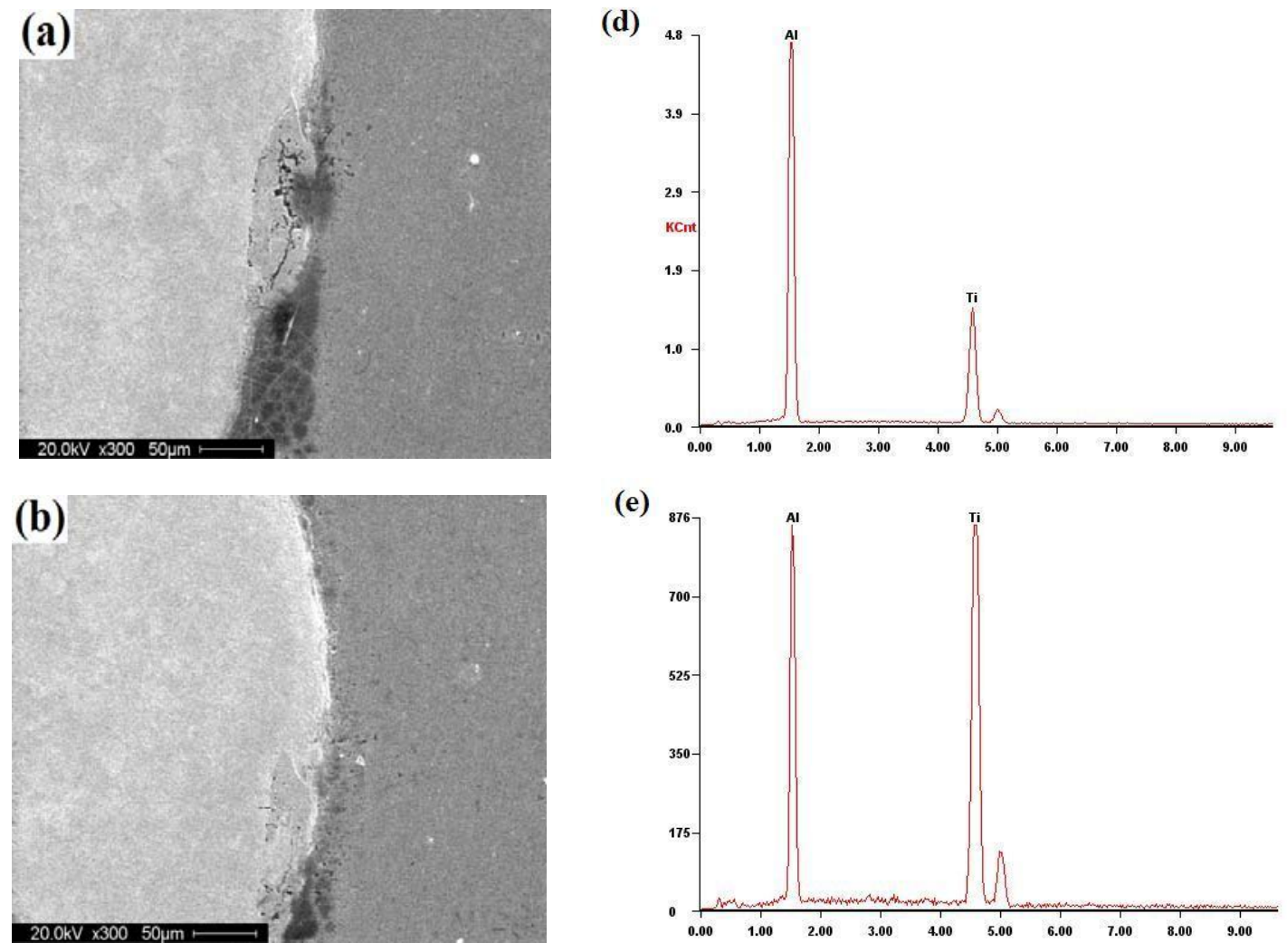

(e)
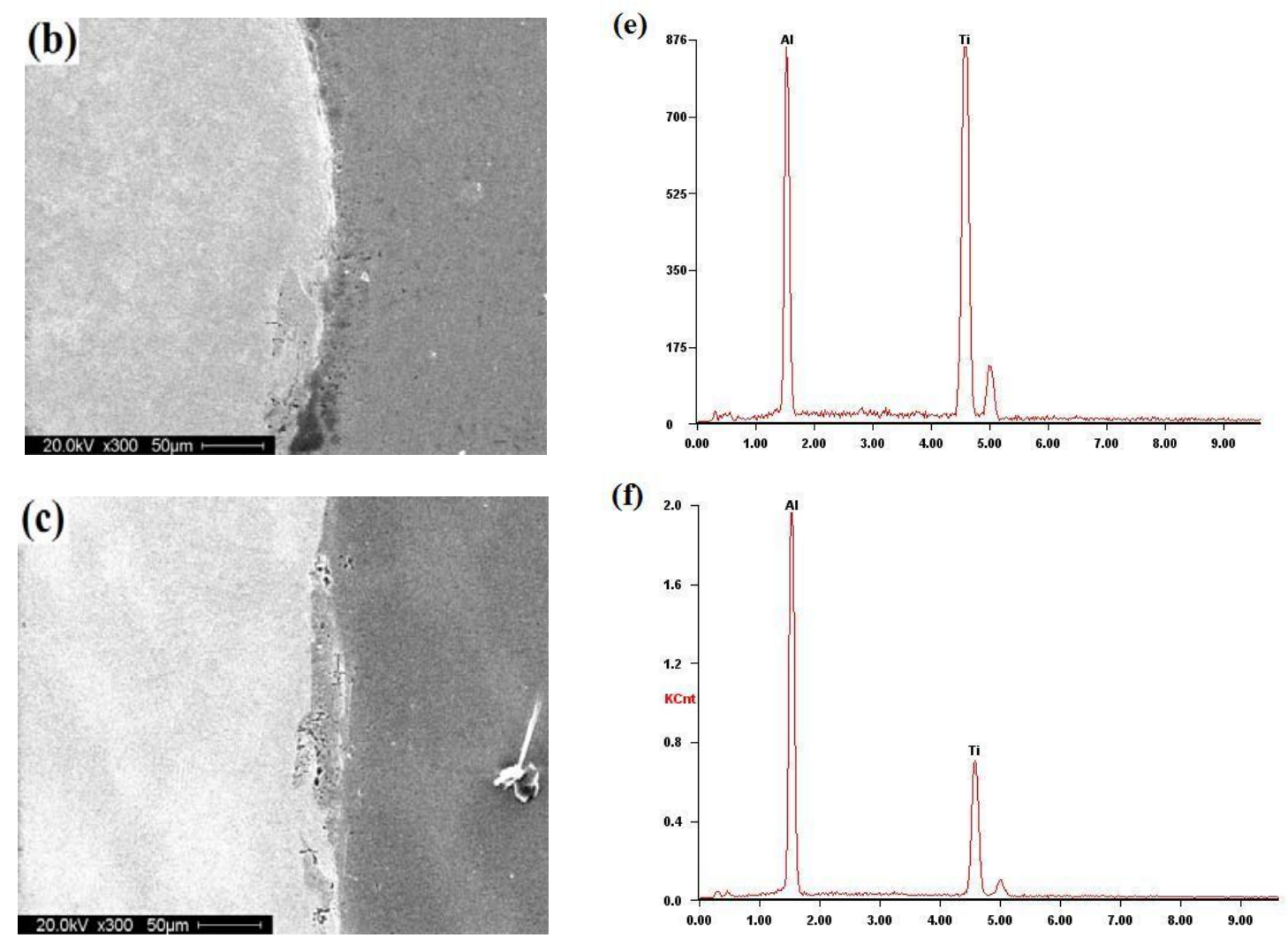

Fig.5 The formation area of intermetallic compound and its corresponding EDS curves: (a)area A $480^{\circ} \mathrm{C} \times 9 \mathrm{~h}$, (b)area B $440^{\circ} \mathrm{C} \times 6 \mathrm{~h}$, (c)area C $480^{\circ} \mathrm{C} \times 6 \mathrm{~h},(\mathrm{~d}) \mathrm{EDS}$ of area $\mathrm{A}$, (e)EDS of area $\mathrm{B}$, and (f)EDS of area C

Table 2 Atom ratio of its corresponding area and the pattern of intermetallic compound

\begin{tabular}{ccc}
\hline Position of selected area & Atom ratio (Ti:Al) & Pattern of intermetallic compound \\
\hline A & $26.11: 73.89(1: 3)$ & $\mathrm{TiAl}_{3}$ \\
B & $54.95: 45.05(1: 1)$ & $\mathrm{TiAl}$ \\
C & $30.1: 69.9(1: 2)$ & $\mathrm{TiAl}_{2}$ \\
\hline
\end{tabular}




\section{Microhardness of composite plate after heat treatment}

The microhardness at the side of titanium near interface under different conditions of heat treatment is given in Table 3. The microhardness of composite plate near interface is the maximum in as-welded state, as described in Ref.[3]. When the heating temperature is $440^{\circ} \mathrm{C}$ and the duration time is $1 \mathrm{~h}$ and $3 \mathrm{~h}$ respectively, compared to the original hardness $208.0 \mathrm{MPa}$ of TA2 near interface in as-welded state, its hardness decreases to a certain extent, but the degree of decrease is not so great. When the duration time prolonged to $6 \mathrm{~h}$, the amplitude of decrease of microhardness is greater, and it reduces to $161.3 \mathrm{MPa}$, which is close to the microhadness of base metal. The amplitude of hardness decrease becomes low with the further increase of duration time. While the heating temperature is $480^{\circ} \mathrm{C}$ and duration time is $3 \mathrm{~h}$, the amplitude of hardness decrease is greater, to $162.8 \mathrm{MPa}$. However the decrease of hardness is not greater with the increase of duration time further. When the annealing is carried out to Ti-Al composite plate, the course of recovery and recrystallization will be gradually generated in the plastic deformation region of material, as a result, the degree of plastic deformation will decrease greatly. At the same time, the cell of dislocation tangle within grain will release due to heating, which results in the decrease of dislocation density. Due to the two factors, the hardness of material decreases. According to the heat treatment process of industrial pure titanium, when annealing is conducted under the condition of $440^{\circ} \mathrm{C} \times 3 \mathrm{~h}$ or $480^{\circ} \mathrm{C} \times 1 \mathrm{~h}$, the process of stress relieving annealing obviously occurs to the side of titanium.

Table 3 Microhardness at the side of titanium near interface with different heat treatment processes

\begin{tabular}{ccccc|cccc}
\hline Heating temperature $/{ }^{\circ} \mathrm{C}$ & \multicolumn{4}{c|}{440} & \multicolumn{4}{c}{480} \\
\hline Duration time $/ \mathrm{h}$ & 1 & 3 & 6 & 9 & 1 & 3 & 6 & 9 \\
\hline Microhardness $/ \mathrm{MPa}$ & 200.7 & 190.7 & 161.3 & 147.7 & 195.4 & 162.8 & 157.9 & 142.2 \\
\hline
\end{tabular}

\section{Shear strength of interface of composite plate after heat treatment}

Shear strength of composite plate under different conditions of heat treatment is tested, as given in Table 4 . When the heating temperature is $440^{\circ} \mathrm{C}$, and the duration time is $1 \mathrm{~h}$ and $3 \mathrm{~h}$, the shear strength of Ti-Al composite plate are $75.8 \mathrm{MPa}$ and $82.3 \mathrm{MPa}$ respectively. Compared to the shear strength $72.1 \mathrm{MPa}$ of composite plate in as-welded state, it increases to a certain extent, and $82.3 \mathrm{MPa}$ is the maximum value after annealing in present work. According to the diffusion degree of atoms at interface, the diffusion layer of alloy element atom is greater under the condition of heat treatment, as shown in Fig.6. The diffusion bonding of atoms is more complete, and it results in the increase of bonding strength between atoms. In terms of the macro-property of composite plate, it presents the increase of shear strength of composite plate. However, the shear strength of composite plate decreases to a certain extent when the duration time is prolonged to $6 \mathrm{~h}$ and $9 \mathrm{~h}$.

Table 4 Shear strength of composite plate under different heat treatment processes

\begin{tabular}{ccccc|cccc}
\hline Heating temperature $/{ }^{\circ} \mathrm{C}$ & \multicolumn{4}{c|}{440} & \multicolumn{4}{c}{480} \\
\hline Duration time $/ \mathrm{h}$ & 1 & 3 & 6 & 9 & 1 & 3 & 6 & 9 \\
\hline Shear strength $/ \mathrm{MPa}$ & 75.8 & 82.3 & 67.4 & 61.5 & 78.3 & 70.5 & 63.4 & 59.7 \\
\hline
\end{tabular}

Although the atom can diffuse more fully with the increase of duration time, the formation of intermetallic compound is probably more easily. Under the condition of duration time $1 \mathrm{~h}$ and $3 \mathrm{~h}$, though the intermetallic compound maybe generates, the strengthening effect of interface due to diffusion of atoms is stronger than the action of weakening by the formation of intermetallic compound, consequently the shear strength of composite plate increases. But when the duration time increases to $6 \mathrm{~h}$ and $9 \mathrm{~h}$, the strengthening effect by atom connecting is less than the action of weakening by the formation of intermetallic compound, as a result, the shear strength of composite 
plate decreases. When the heating temperature is $480^{\circ} \mathrm{C}$, the variation is the same as the above, but the inflection point of duration time is $1 \mathrm{~h}$ associated with the decrease of shear strength.

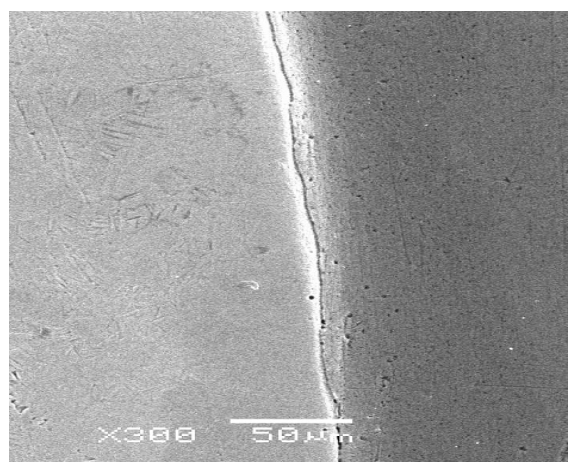

Fig.6 Connection band of atom diffusion

The effect of heat treatment on both of the microhardness and shear strength of composite plate is comprehensively considered, and the annealing process of TA2-2A12 composite plate is determined as: $440^{\circ} \mathrm{C} \times 3 \mathrm{~h}$.

\section{Conclusions}

The observation of metallurgical structure indicates that, the interface of Ti-Al composite plate presents the ideal wavy connection, and the dislocations exist near interface of both the sides of titanium and aluminum, the dislocation density in the side of titanium is higher than that in the side of aluminum.

Tests of mechanical properties illustrate that, compared to the composite plate before heat treatment, the shear strength of interface arrives to the maximum when the heating temperature is $440^{\circ} \mathrm{C}$ and the duration time is $3 \mathrm{~h}$, which is $82.3 \mathrm{MPa}$. The measurement of microhardness of interface demonstrates that, the higher the heating temperature and the longer the duration time is, the greater the microhardness near interface decreases.

The EDS analyses of interface of composite plate demonstrate that, under the three conditions of heat treatment: $480^{\circ} \mathrm{C} \times 9 \mathrm{~h}, 440^{\circ} \mathrm{C} \times 6 \mathrm{~h}, 480^{\circ} \mathrm{C} \times 6 \mathrm{~h}$, intermetallic compound generated to a certain extent in all of the interfaces of composite plates, and the corresponding patterns of intermetallic compounds are: $\mathrm{TiAl}_{3}, \mathrm{TiAl}$ and $\mathrm{TiAl}_{2}$, respectively.

Considering comprehensively all of the influencing factors, under the experimental condition in present work, the annealing process of TA2-2A12 composite plate is determined as: $440^{\circ} \mathrm{C} \times 3 \mathrm{~h}$.

\section{Acknowledgements}

This work is financially supported by A Project Funded by the Priority Academic Program Development of Jiangsu Higher Education Institutions, which is gratefully acknowledged.

\section{References}

[1] W. Xu, M. Zhu, S.L. Guo, J. Hu and D.F. Li: Chinese Journal of Rare Metals Vol.35(2011), p.342 (In Chinese)

[2] S.A.A. Akbari Mousavi and P. Farhadi Sartangi: Mater Sci Eng A Vol.494(2008), p.329

[3] M. Acarer, B. Gülenç and F. Findik: Mater Des Vol.24(2003), p.659

[4] F. Findik: Mater Des Vol.32(2011), p.1081

[5] U.R. Kattner, J.-C. Lin and Y.A. Chang: Metall Trans A Vol.23(1992), p.2081 